\title{
A qualitative study on dietary habits and nutritional awareness among school children
}

\author{
Geethika Koneru $^{1 *}$, N.S. Sanjeeva Rao ${ }^{2}$, T.S.R.Sai ${ }^{3}$ \\ ${ }^{1}$ Post Graduate, ${ }^{2}$ Professor, ${ }^{3}$ Professor and Head, ${ }^{1-3}$ Dept. of Community Medicine, NRI Medical College, Guntur, \\ Andhra Pradesh, India
}

Corresponding Author: Geethika Koneru

Email: geethikakoneru@gmail.com

\begin{abstract}
Introduction: Though poorly documented, older school going children in India are also subject to malnutrition. Children in this age group especially require increased proteins and micronutrients during their growth spurt. Research on their nutritional behaviour and dietary habits is scanty.

Objective: To understand knowledge regarding nutrition and dietary habits among secondary school children with the use of qualitative research methods.

Materials and Methods: This study involving students of $8^{\text {th }}$ to $10^{\text {th }}$ grades in a school in Mangalagiri, Andhra Pradesh was done in November 2017. Focus group discussions were conducted by grade and gender. Information obtained was triangulated by key informant interviews (local paediatrician, school teacher) and literature search. The sessions were recorded and transcribed diligently. Emerging themes were identified about knowledge and behaviour.

Results: The themes identified were - Knowledge about specific nutrients and balanced diet, Role of diet in preventing disease, Food preferences among school children, Misconceptions about foods, Gender differences in dietary habits, Influence of junk food, Body image and exercise. Knowledge obtained from school curriculum was limited and children were influenced more by cues from family and media. According to one ninth grader "Brown rice is healthy but not at all tasty". Another boy said "Junk food sometimes gives me a stomach upset, but it is too good to give up"

Conclusion: Qualitative research gives an in-depth picture of issues which are difficult to capture. While school children have some insights into nutrition, there are lacunae. A more informative school curriculum would prevent the development of wrong attitudes in children.
\end{abstract}

Keywords: Qualitative, School children, Nutritional awareness, Dietary habits.

\section{Introduction}

When talking about nutritional status of children in India, importance is given to under-five children and the children above five years are comparatively neglected. Though poorly documented, school children in India are subject to malnutrition. Malnutrition, the condition resulting from faulty nutrition, weakens the immune system and causes significant growth and cognitive delay. ${ }^{1}$ Older children especially require increased proteins and micronutrients during their growth spurt. Unfortunately, once they cross the age of five, children are not followed as closely. Research on their nutritional behaviour and dietary habits is scanty.

The nutritional status of a child can cause and precipitate many health problems such as anaemia, obesity, refractive errors of the eye, increased susceptibility to infectious diseases and psychological issues such as eating disorders, body image issues and can even affect the child's performance at school. Even though obesity and overweight are increasing in recent times; under nutrition is still prevalent in adolescent school children. ${ }^{2}$

Although genetic and environmental factors play crucial role in the aetiology of obesity, lack of education on the healthy life style approach and behavioural attitudes towards food remain to be important direct factors for obesity. ${ }^{3}$

The dietary habits learnt in childhood often carry on to adulthood and can affect the long-term health of the individual. School children, despite their easy accessibility, are not adequately assessed for their knowledge and attitudes towards diet and eating 
practices. The school presents an opportune setting to assess and educate children regarding healthy dietary habits and the importance of nutrition and diet in achieving and maintaining optimum health.

Qualitative research is a process of inquiry that seeks in-depth understanding of social phenomena within their natural setting. It focuses on the "why" rather than the "what" of social phenomena and relies on the direct experiences of human beings in their everyday lives. ${ }^{4}$ Quantitative methods often fail to give an in-depth understanding of the issues underlying a health problem or a health-related behaviour, acceptability and utilisation of a health service and so on and so forth. Qualitative researchers use multiple systems of inquiry such biography, case study, ethnography, grounded theory, phenomenology, focus group discussions, in-depth interviews etc. These methods help to gather the information in the participant's own words and helps uncover the causative factors affecting their behaviour and attitudes regarding health.

Interviews and focus groups remain the most common methods of data collection in qualitative research. Interviews can be used to explore the views, experiences, beliefs and motivations of individual participants. ${ }^{5}$ Triangulation refers to the use of multiple methods or data sources to develop a comprehensive understanding of phenomena. Triangulation is also a qualitative research strategy to test validity through the convergence of information from different sources. ${ }^{6}$

\section{Objective}

To understand knowledge regarding nutrition and dietary habits among secondary school children with the use of qualitative research methods.

\section{Materials and Methods}

This study involving students of $8^{\text {th }}$ to $10^{\text {th }}$ grades in a school in Mangalagiri, Andhra Pradesh was done in November 2017. Six focus group discussions, involving 65 students were conducted and the information obtained was triangulated by key informant interviews and literature search. Emerging themes were identified about knowledge and behaviour.

\section{Focus Group Discussions (FGDs)}

Six Focus Group Discussions were conducted. Each FGD comprised of 8 to 12 students, The 65 students involved in the study were from classes 8 to 10 . Focus group discussions were conducted based on their grade and gender. Thus three of the FGDs consisted of only male students, while the other three FGDs consisted of only female students. The awareness and perceptions of the students regarding nutrition were assessed separately for the male and female students. Differences regarding health perceptions and behaviours in the different grades were also noted. In each FGD, the students were seated in a circle while the principal investigator acted as the moderator of the group. Each FGD was carried on until an information saturation point had been reached. All the sessions were recorded with an audio recorder and were later transcribed carefully.

\section{Key Informant Interviews (KIIs)}

Two Key Informant Interviews were conducted, one with the school life sciences teacher, and the other with the local paediatrician in Mangalagiri town. Each KII was conducted by the principal investigator at the workplace of the key informant. The purpose of the study and the need for their professional opinions was explained to them and privacy was ensured while conducting the interviews. The sessions were recorded using an audio recorder and were later transcribed diligently.

\section{Results}

The findings from the FGDs have been summarised in Table 1. The findings from the Key Informant Interviews (KIIs), which were used to triangulate the information obtained, have been summarised in Table 2.

The following seven themes have been identified in this study:-

\section{Knowledge about specific nutrients and balanced diet}

It was found through the focus group discussions that the children had adequate knowledge regarding balanced diet and the principal components it 
comprised of. They were aware that nutrients were of different types such as carbohydrates, proteins, fats and vitamins. They named rice and wheat as carbohydrate-rich foods, milk and egg as protein-rich foods and fruits were named as the foods rich in vitamins. They said that carbohydrates were essential for energy and proteins for growing tall and healthy. They named vitamins A, C and D, and said they needed them for healthy skin and hair. They were aware that Vitamin A was important for having healthy vision and that it was available in carrots. They did not know what minerals were. All the children thought that fats were found in junk food such as samosas and chips. A few children in $10^{\text {th }}$ standard named cooking oils as sources of fats in diet. Despite knowing that fats were part of the balanced diet, none of the children were aware of the role of fats in being healthy and thought that they shouldn't be consumed. None of them knew the importance of calcium in diet or its food sources. They did not have adequate knowledge about iron-rich foods. None of the children knew what dietary fibre was or its importance in diet.

\section{Role of diet in preventing disease}

The children knew that nutrition played an important role in diseases and named diabetes, obesity, anaemia and hypertension as diseases caused due to improper diet intake. However, none of them knew how the food they ate could result in these diseases, and so didn't know how these diseases could be prevented or how to modify their diet in order to prevent them.

\section{Food preferences among school children}

Dal, rice and fruits were part of their regular diet. More girl students were eating fruits than boy students were. The children were aware that millets and brown rice were healthy foods, but didn't want to eat them as they were considered tasteless. Food items such as spinach, tomato, egg and milk were considered unpalatable by some.

According to one ninth grader "Brown rice is healthy but not at all tasty". Another girl said "I hate the smell of egg and no matter now nutritious it is I cannot eat it".

\section{Misconceptions about foods}

All of them were under the misconception that iron was important in diet as it increases the strength of bones.

\section{Gender differences in dietary habits}

The children were eating more during holidays and less during exams time. Female students were more forthcoming to changing their dietary habits than male students for attaining better health.

\section{Influence of junk food}

They knew that junk food was not healthy for them yet ate it. Most of their junk food intake was during school breaks and after-school, from nearby shops.

One student said "Junk food sometimes gives me a stomach upset, but it is too good to give up".

\section{Body image and exercise}

Although most of the children had a healthy body image, some admitted to going on diets and lifting weights due to influence of media. The boys were going on diets more than the girl students. The boys who were lifting weights also said they ate 3 or 4 eggs per day as it would increase the bulk of their muscles.

"I want to develop a muscular body with six-pack abs like a movie hero" $-8^{\text {th }}$ grade boy who was lifting weights on weekends at a nearby gym.

They were aware of the importance of exercise in maintaining good health. They were playing games such as volleyball, throw ball and kabaddi during their games period, which was for forty-five minutes every day. Some girls were also doing yoga at school or at home. The children said they couldn't do more exercise due to lack of time, as they needed to study. Some also stated that as there was no local park to walk or jog in, they couldn't exercise more even if they wanted to. 
Table 1: Findings of Focus Group Discussions (FGDs)

The findings from the six FGDs can be grouped into the following seven themes:

\begin{tabular}{|c|c|c|}
\hline Theme & Helpful & Unhelpful \\
\hline $\begin{array}{l}\text { i. Knowledge } \\
\text { about specific } \\
\text { nutrients and } \\
\text { balanced diet }\end{array}$ & $\begin{array}{l}\text { Deficiencies in knowledge - The children } \\
\text { were aware of balanced diet as it was a } \\
\text { part of their syllabus. } 8^{\text {th }} \text { and } 9^{\text {th }} \text { grade } \\
\text { students had less knowledge regarding } \\
\text { foods rich in specific vitamins and } \\
\text { minerals and importance of dietary fibre } \\
\text { compared to the } 10^{\text {th }} \text { graders. All of them } \\
\text { were aware of the importance of vitamin A } \\
\text { and named carrots as its source. }\end{array}$ & $\begin{array}{l}\text { Students had less knowledge regarding } \\
\text { foods rich in specific vitamins and } \\
\text { minerals, and the importance of dietary } \\
\text { fibre and calcium in their diet. }\end{array}$ \\
\hline $\begin{array}{l}\text { ii. Role of diet in } \\
\text { preventing disease }\end{array}$ & $\begin{array}{l}\text { Incomplete knowledge - They were aware } \\
\text { of diseases where nutrition has a role - } \\
\text { anaemia, diabetes, hypertension and } \\
\text { obesity. }\end{array}$ & $\begin{array}{l}\text { None of them knew how the food they } \\
\text { ate could result in these diseases. They } \\
\text { were not aware of the exact role of diet } \\
\text { in preventing these diseases. }\end{array}$ \\
\hline $\begin{array}{l}\text { iii. Food } \\
\text { preferences among } \\
\text { school children }\end{array}$ & $\begin{array}{l}\text { Imbalance between healthy \& tasty - } \\
\text { The children ate dal, rice and fruits } \\
\text { regularly and knew that these food items } \\
\text { were rich in proteins, carbohydrates and } \\
\text { vitamins respectively. }\end{array}$ & $\begin{array}{l}\text { Food items such as spinach, tomato, egg } \\
\text { and milk were considered unpalatable } \\
\text { by some. They were aware that millets } \\
\text { and brown rice were healthy foods, but } \\
\text { didn't want to eat them as they were } \\
\text { considered tasteless. }\end{array}$ \\
\hline $\begin{array}{l}\text { iv. Misconceptions } \\
\text { about foods }\end{array}$ & $\begin{array}{l}\text { Erroneous knowledge \& Influence of } \\
\text { media - Students knew that they should } \\
\text { take foods rich in iron. They also knew } \\
\text { that milk was an important food. }\end{array}$ & $\begin{array}{l}\text { Misconceptions are that iron is needed } \\
\text { for strengthening the bones. They were } \\
\text { not aware of the presence and role of } \\
\text { calcium in the milk. Consuming milk } \\
\text { with specific energy powders would } \\
\text { make them grow taller and stronger, as } \\
\text { advertised on TV. }\end{array}$ \\
\hline $\begin{array}{l}\text { v. Gender } \\
\text { differences in } \\
\text { dietary habits }\end{array}$ & $\begin{array}{l}\text { Girls more healthy diet conscious - The } \\
\text { Female students were more forthcoming to } \\
\text { changing their dietary habits than male } \\
\text { students for attaining better health. }\end{array}$ & $\begin{array}{l}\text { Children were eating more during } \\
\text { holidays and less during exams time. }\end{array}$ \\
\hline $\begin{array}{l}\text { vi. Influence of } \\
\text { junk food }\end{array}$ & $\begin{array}{l}\text { Attraction of junk foods - Students knew } \\
\text { that junk food was not healthy for them. }\end{array}$ & $\begin{array}{l}\text { Most of their junk food intake was } \\
\text { during school breaks and after-school, } \\
\text { from nearby shops. They knew that junk } \\
\text { food was not healthy for them yet ate it. }\end{array}$ \\
\hline $\begin{array}{l}\text { vii. Body image } \\
\text { and exercise }\end{array}$ & $\begin{array}{l}\text { Body image, exercise \& diet -Most of the } \\
\text { children had a healthy body image. They } \\
\text { were aware of the importance of exercise } \\
\text { in maintaining good health. }\end{array}$ & $\begin{array}{l}\text { Some admitted to going on diets and } \\
\text { lifting weights due to influence of } \\
\text { media.Games at school and yoga were } \\
\text { the only exercise they were doing. }\end{array}$ \\
\hline
\end{tabular}


Table 2: Findings from Key Informant Interviews (KIIs)

\begin{tabular}{|c|c|}
\hline Interview with School Teacher & $\begin{array}{l}\text { "The children take a lot of stress during exam times, and even for tests } \\
\text { due to the pressure put on them by their parents and the society. They } \\
\text { sometimes skip breakfast which leads to dizziness and fainting spells" } \\
\text { When asked about the curriculum, she said "Their syllabus doesn't } \\
\text { include much about the effect of nutrition on health" }\end{array}$ \\
\hline Interview with local paediatrician & $\begin{array}{l}\text { "Children eat what their family eats. Their parents influence their } \\
\text { attitude towards health. They are not taught how to practically apply } \\
\text { their knowledge of nutrition. With the increasing trends of anaemia, } \\
\text { childhood obesity, eating disorders and with the increasing incidence } \\
\text { of diabetes and hypertension in young adults, it is vital to establish a } \\
\text { healthy attitude and proper eating behaviours in childhood itself" }\end{array}$ \\
\hline
\end{tabular}

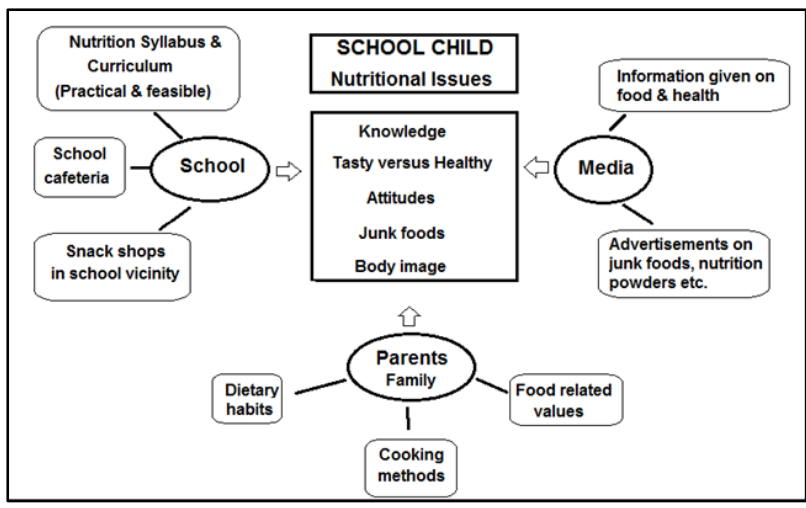

Fig. 1: Thematic diagram - school child nutrition

\section{Discussion}

In a review of literature which included studies from multiple countries, it was found that the nutritional status of school-aged children, especially those of Southeast Asia and Africa was inadequate. Malnutrition has found to be a public health issue in school-aged children in developing countries and countries in transition. ${ }^{7}$ In a study conducted in Nairobi, Kenya, it was found that school children had moderate nutrition knowledge and poor dietary practices, associated with negative dietary attitude. ${ }^{8}$ Srivatsava et al in their study in an urban slum in India, found that most of the school-age children had a poor nutritional status. Prevalence of stunting and underweight was found to be highest in the age group of 11-13 years. ${ }^{1}$

The information identified in the present study through the six focus group discussions shed light on the perceptions of the school children regarding balanced diet and specific nutrients, the role of diet in preventing disease, their daily food preferences, certain misconceptions they had about foods, the gender differences in their dietary habits, the influence

of junk food on their food intake, body image and exercise.

In a three year health education programme conducted in Mumbai, it was found that students had a poor/unsatisfactory knowledge regarding several factors affecting health, including nutrition. This study also found that girls had comparatively better understanding than boys regarding health issues. ${ }^{9}$ The present study also found inadequate knowledge of the school children regarding nutrition. Girl students were found to be more willing to change their diet patterns for the better than the boys.

This gender difference in attitudes towards healthy diet is supported by Shah $\mathrm{P}$ et al who conducted a school-based health and nutritional education programme on knowledge and behaviour of urban Asian Indian school children and found a significantly higher improvement in girls compared with boys, after the intervention. ${ }^{10}$ Swaminathan et al also found that knowledge regarding healthy diet varied based on gender, although other factors such as age group, mother's educational level, and SES also played a role. 11

The children were under the misconception that iron was required in diet to increase the strength of the bones. Girls were aware that menstruation causes blood loss and said that it might make them 'weak and cause them to faint'. However not knowing the 
importance of iron prevented them from taking appropriate diet to help prevent anaemia.

A lack of understanding of food-nutrient and foodhealth association was found in a similar study conducted in UK. ${ }^{12}$ A dietary survey assessing anaemia and under nutrition in school children in Kerala also found that consumption of iron sources was below the recommended level. ${ }^{13}$ With the high prevalence of anaemia in India, especially amongst females and children, the school children's lack of knowledge regarding iron-rich foods is a cause for concern.

It was found in the FGDs that the children's dietary habits were irregular during exams. They were skipping meals and snacking on unhealthy foods due to exam stress. On interviewing the school teacher, she said, "They sometimes skip breakfast which leads to dizziness and fainting spells" In a mixed methods study conducted on school-going adolescents in Baroda, India, it was found that nearly $40 \%$ of the students missed taking breakfast daily. Nearly onethird of adolescents were missing a meal once or twice a week. $^{14}$

It has been found that obese and overweight children had frequent preference to sweet and fatty food snacks compared to children with normal weight. ${ }^{15}$ In UAE, it has been found that dietary habits in the form of skipping breakfast and eating fast food have been identified as major cause of obesity in adolescents. ${ }^{16}$ On further questioning the students, it was found that most often, the cause for skipping a meal and snacking on fast foods was because they said they didn't have the time to eat, either because they woke up late in the morning, or because they needed to study for a test during a lunch break, or because the exam stress made them lose their appetite. Going on diets was not given as reason for skipping a meal.

It was found in this study that the school children, especially boys, were consuming junk food such as potato chips and samosas regularly, despite knowing they were not healthy. They were buying them from road-side shops nearby after school, which raises a doubt regarding the quality of the food as well.

"Junk food sometimes gives me a stomach upset, but it is too good to give up". $9^{\text {th }}$ grade student
Vijayapushpam et al conducted a study on school children in Hyderabad and found an increased intake of fast foods and carbonated beverages by the children irrespective of SES in their study. ${ }^{17}$ In a similar qualitative study conducted on school children in India, it was found that Indian middle socioeconomic status students were already moderately aware of the health benefits to nutritious food intake and physical activity, but parents, schools, and the media could influence unhealthy behaviours. ${ }^{18}$

Joseph $\mathrm{N}$ et al, in their study conducted on male school children in Mangalore, found that $64.3 \%$ of participants were introduced to fast foods through television. Parental consumption of fast foods was found to be a significant factor that influenced fast food consumption among children, and increased frequency of fast food consumption in a week was found to be associated with overweight or obesity among children. ${ }^{19}$

It has been recommended that children aged 6 - 17 years should participate in a minimum of 60 minutes of exercise daily. ${ }^{20}$ However, the only exercise the children in this study were doing was playing games such as volleyball, throw ball and kabaddi during their games period, which was for forty-five minutes every day. Some girls were also doing yoga at school or at home. The children said they couldn't do more exercise due to lack of time and due to lack of a local park to exercise in. Some of the boys said they went to gym to lift weights to develop a muscular body.

It was apparent on further discussion, that movies and TV advertisements played a major role in shaping the children's views regarding body image and the need to 'be cool'. These perceptions influenced the children to eat the foods advertised by their favourite movie stars and to wish for a body like theirs. This was observed more in the male school children than the females. The children even thought that it wasn't plain milk, but the energy powder mixed with the milk that made them taller and healthier, because that's what the TV advertisements said.

"The syllabus doesn't include much about the effect of nutrition on health". Teacher of Life Sciences from the school

According to her, knowledge obtained from school curriculum regarding nutrition and health was limited 
and children were influenced more by cues from family and media.

"Children eat what their family eats. Their parents influence their attitude towards health. They are not taught how to practically apply their knowledge of nutrition." - Local paediatrician

With the increasing exposure of children to media and less control of their food habits by their parents, the possibility of controlling the epidemics of chronic diseases and nutrition-related disorders is a challenge. While school children have some insights into nutrition, they need to be taught how to practically apply it in their everyday life. Educational intervention programmes could go a long way in establishing healthy life habits in children.

\section{Conclusion}

The foundations for the accurate knowledge and attitude towards health should be laid in childhood. With chronic conditions such as diabetes, obesity, hypertension and anaemia on the rise, school children are an affective audience to impart health education to. It is imperative to help develop the right attitude towards diet and nutrition. Using qualitative methods to understand the children's perceptions towards diet and exercise, and moulding these perceptions early on in life can go a long way in decreasing the morbidity and health expenditure caused by chronic nutrition related disorders. Conducting health education workshops or including more information about foodnutrient and food-health association in the school curriculum would be an effective measure to bring about healthy attitudes.

\section{Source of Funding}

None.

\section{Conflict of Interest}

None.

\section{References}

1. Srivastava A, Mahmood SE, Srivastava PM, Shrotriya VP, Kumar B. Nutritional status of school-age children-A scenario of urban slums in India. Arch Public Health 2012;70(1):8

2. Selvaraj V, Sangareddi S, Velmurugan L, Muniyappan U, Anitha FS, Nutritional status of adolescent school children in a semi-urban area based on anthropometry. Int $J$ Contemp Pediatr 2016; 3(2):468-72

3. Deeb A, Suliman S, Tomy M, Yousef H, Rahman LA, Saleh S et al, Is There a Correlation between Body Weight and Awareness of Healthy Life Style Components in Children?. Open J Pediatr 2015; 5(01):49 - 55.

4. What is qualitative research? Emma Eccles Jones Research Centre, University of Utah, College of Nursing, https://nursing.utah.edu/research/qualitative-research/ what-is-qualitative-research.php

5. Gill P, Stewart K, Treasure E, Chadwick B. Methods of data collection in qualitative research: interviews and focus groups. Br Dent J 2008; 204(6):291

6. Carter N, Bryant-Lukosius D, DiCenso A, Blythe J, Neville AJ. The use of triangulation in qualitative research, Oncol Nurs Forum 2014; 41(5): 545- 7.

7. Best C, Neufingerl N, Van Geel L, van den Briel T, Osendarp S. The nutritional status of school-aged children: why should we care? Food Nutr Bull 2010;31(3): 400-17.

8. Kigaru DM, Loechl C, Moleah T, Macharia-Mutie CW, Ndungu ZW. Nutrition knowledge, attitude and practices among urban primary school children in Nairobi City, Kenya: a KAP study. BMC Nutr 2015;1(44): 1-8

9. Mahajan BS, Chunawala S. Indian secondary students' understanding of different aspects of health. Int J Sci Educ 1999; 21(11):1155-68.

10. Shah P, Misra A, Gupta N, Hazra DK, Gupta R, Seth P et al, Improvement in nutrition-related knowledge and behaviour of urban Asian Indian school children: findings from the 'Medical education for children/Adolescents for Realistic prevention of obesity and diabetes and for healthy ageing'(MARG) intervention study. Br J Nutr 2010;104(3): 427-36.

11. Swaminathan S, Thomas T, Kurpad AV, Vaz M. Perceptions of healthy eating: A qualitative study of school-going children in South India. Health Educ J 2009; 68(2): 94-110.

12. Hart KH, Bishop JA, Truby H. An investigation into school children's knowledge and awareness of food and nutrition. J Hum Nutr Diet 2002;15(2):129-40.

13. George KA, Kumar NS, Lal JJ, Sreedevi R. Anaemia and nutritional status of pre-school children in Kerala. Indian $J$ Paediatr 2000; 67(8):575-8.

14. Kotecha PV, Patel SV, Baxi RK, Mazumdar VS, Shobha M, Mehta KG et al, Dietary pattern of school going adolescents in urban Baroda, India. J Health, Population, Nutr 2013; 31(4):490.

15. Sharma A, Hegde A. Relationship between body mass index, caries experience and dietary preferences in children. J Clin Paediatr Dent 2009; 34(1): 49-52.

16. bin Gazaal A.A, Musaiger A.O. and D’Souza R. (2009) Dietary Habits Associated with Obesity among Adolescents in Dubai, United Arab Emirates. Nutrición Hospitalaria 2009; 24: 437-4.

17. Vijayapushpam T, Menon KK, Rao DR, Antony GM. A qualitative assessment of nutrition knowledge levels and 
dietary intake of schoolchildren in Hyderabad. Public Health Nutr 2003;6(7):683-8.

18. Riggs N, Tewari A, Stigler M, Rodrigues L, Arora M, Khubchandani J et al, Indian students' perspectives on obesity and school-based obesity prevention: a qualitative examination. Health Promotion Pract 2013;14(6): 816-23.

19. Joseph N, Nelliyanil M, Rai S, YP RB, Kotian SM, Ghosh $\mathrm{T}$ et al, Fast food consumption pattern and its association with overweight among high school boys in Mangalore city of southern India. JCDR 2015; 9(5): LC13.
20. US Department of Health and Human Services (2008) Physical Activity Guidelines Advisory Committee Report. US Department of Health and Human Services, Washington DC.

How to cite this article: Koneru G, Rao NSS, Sai TSR. A qualitative study on dietary habits and nutritional awareness among school children. $J$ Community Health Manag 2019;6(4):105-12. 